\title{
Evaluation of Prognostic Significance of Immunological Cells (Tissue Eosinophil and Mast Cell) Infiltration in Oral Squamous Cell Carcinoma
}

\section{Priyanka Debta $^{1 *}$, Fakir Mohan Debta ${ }^{2}$, Minal Chaudhary ${ }^{3}$ and Vijay Wadhwan ${ }^{4}$}

${ }^{1}$ Department of Oral Pathology and Microbiology, Chhattisgarh Dental College and Research institute, India

${ }^{2}$ Department of Oral Medicine \& Radiology, C.D.C.R.I. Sundra, Rajnandgaon, Chhattisgarh, India

${ }^{3}$ Department of Oral Pathology and Microbiology, S.P.D.C., Sawangi, Wardha, Maharashtra, India

${ }^{4}$ Department of Oral Pathology and Microbiology, I.T.S. Dental College, Murad Nagar, Ghaziabad, India

\begin{abstract}
Background: In oral carcinoma much effort has been made to predict the prognosis of patients but a sound understanding of underlying cell biology is likely to need progress. Recently, attention has been directed towards tumour associated tissue eosinophils and mast cells and their role in the biologic behavior of tumours.
\end{abstract}

Aim: The retrospective study was used to evaluate the influence of tumour associated tissue eosinophils and mast cells on prognosis of oral squamous cell carcinoma (OSCC).

Material and methods: The follow-up, of histopathologically diagnosed thirty cases of OSCC, was carried out for minimum period of 3 years. Special stains are wonderful they allow us to see which we can not see clear with routine H\&E stain.Tissue sections were stained with special stains, Carbol Chromotrope for tissue eosinophil and Toluidine blue for tissue mast cell staining.

Result: The results of the present study shows that increase infiltration of tissue eosinophils and mast cells in OSCC, associated with favourable prognosis.

Conclusion: We concludes that infiltration of tissue eosinophils and mast cells are indicators of favourable prognosis in OSCC. Thus quantitative assessment of eosinophils and mast cells are the most important aspects of the microscopic evaluation of OSCC.

\section{Keywords: OSCC; Eosinophil; Mast cell}

\section{Introduction}

Cancer kills or maims thousands of lives each day. Oral squamous cell carcinoma (OSCC) implies quite significant mortality and morbidity rates [1]. The World Health Organization (WHO) predicts a continuing worldwide increase in the incidence of oral cancer, extending this trend into the next several decades. Even now, half of the patients affected with the diseases die within the first two years of diagnosis and oral cancer is expected to become a major public health problem in foreseeable future. This motivates the search of factors with prognostic relevance in order to better tailor the individual management of OSCC patients [2,3].

Although the clinical TNM (Tumour, lymph node, metastasis) staging system is used routinely, it is not always accurate in the prediction of prognosis of head and neck carcinomas as evidenced by $25 \%$ of T1 tumours behaving aggressively and showing an unexpectedly poor prognosis [4]. Thus, the major drawback of clinical staging is the lack of ability to quantify biologic aggressiveness of a tumour on a cellular level [5].

Traditionally the degree of tumour differentiation is used for the prediction of prognosis in squamous cell carcinoma of the oral cavity. However, it is well known that while some cases with well differentiated squamous cell carcinoma may have a favourable prognosis, others with the same histological features do not [6]. Thus there is an agreement in various studies that WHO grade alone shows poor correlation with outcome and response to treatment in an individual patient [7-9].

Tumour stroma consists of various inflammatory cells like lymphocytes, macrophages, neutrophils, plasma cells, mast cells and eosinophils. The inflammatory cells in tumour stroma are result of host response to tumour cells [8]. Recently, attention has been directed towards tumour associated tissue eosinophils and mast cells and their role in the biologic behavior of tumours. The controversy about the actual role of tumour associated tissue eosinophil and mast cell still exists, some studies have correlated infiltration of these cells with favourable prognosis, nevertheless, unfavourable association has also been reported [10]. So in the search of new prognostic and predictive factors for OSCC and addressing this controversy, our study aimed to evaluate the prognostic significance of tissue eosinophil and mast cell infiltration in OSCC.

\section{Materials and Methods}

The present study was carried out in the Department of Oral Pathology and Microbiology, Sharad Pawar Dental College and Hospital, after obtaining approval from the Institutional Ethical Committee, Datta Meghe Institute of Medical Sciences, Sawangi (M), Wardha, Maharashtra. This was a retrospective study with the sample

*Corresponding author: : Dr. Priyanka Debta, MDS, Senior Lecturer, Oral Pathology and Microbiology, Staff Quarter No. 8/16, College campus, Chhattisgarh Dental College and Research institute, PB No.25, Sundra, Rajnandgaon, (C.G.) 491441, India, Tel: 09685714325; E-mail: drpriyanka_1234@rediffmail.com

Received August 08, 2011; Accepted September 17, 2011; Published Septembe 19, 2011

Citation: Debta P, Debta FM, Chaudhary M, Wadhwan V (2011) Evaluation of Prognostic Significance of Immunological Cells (Tissue Eosinophil and Mast Cell) Infiltration in Oral Squamous Cell Carcinoma. J Cancer Sci Ther 3: 201-204. doi:10.4172/1948-5956.1000089

Copyright: () 2011 Debta P, et al. This is an open-access article distributed under the terms of the Creative Commons Attribution License, which permits unrestricted use, distribution, and reproduction in any medium, provided the original author and source are credited. 
Citation: Debta P, Debta FM, Chaudhary M, Wadhwan V (2011) Evaluation of Prognostic Significance of Immunological Cells (Tissue Eosinophil and Mast Cell) Infiltration in Oral Squamous Cell Carcinoma. J Cancer Sci Ther 3: 201-204. doi:10.4172/1948-5956.1000089

size of 30 histological diagnosed cases of OSCC. The follow-up of these cases was carried out for minimum period of 3 years. OSCC group further divided into two categories: - 1) Patients who had survived for $\geq 3$ years $(n=14)$. 2) Patients who dead within $<3$ years $(n=16)$. In this study, good prognosis were considered for patients who had survived for a minimum of 3 years or more, whereas patients who died within 3 years of receiving treatment were considered to have a poor prognosis. Special stain $[10,11]$ used in study are - 1) $1.5 \%$ Carbol Chromotrope for tissue eosinophil staining 2) $0.5 \%$ Toluidine blue for tissue mast cell staining. Figure 1 showing carbol chromotrope stained OSCC section showing tissue eosinophils. Figure 2 showing toluidine blue stained OSCC section showing mast cells. We have randomly selected 10 high density areas of infiltration of tissue eosinophil/mast cells in tumour stroma at higher magnification (400X) for counting of these cells. All the slides were observed by two more examiners for proper evaluation of these cells in special stained OSCC section.

Inclusion criteria of study: 1) Histopathologically diagnosed cases. 2) Surgically operated cases. 3) Intra oral primary tumour cases of OSCC. Exclusion criteria of study: 1) Patients who have been treated

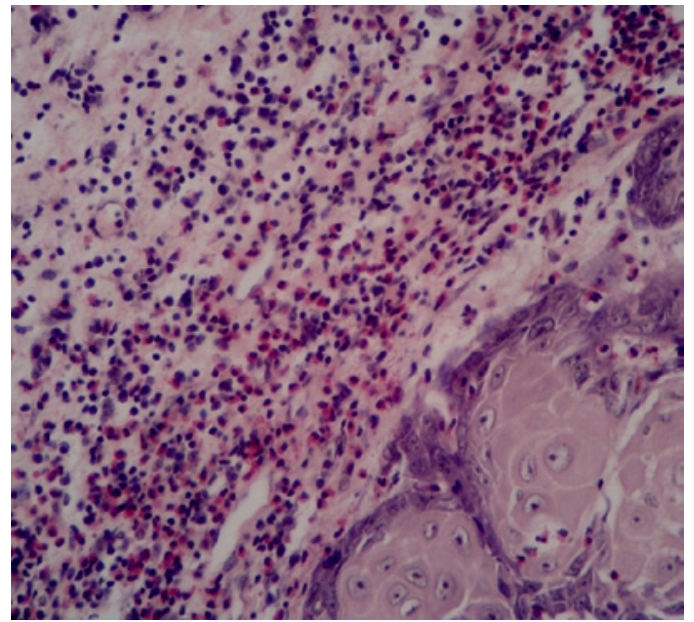

Figure 1: Carbol chromotrope stained OSCC section showing tissue eosinophils.

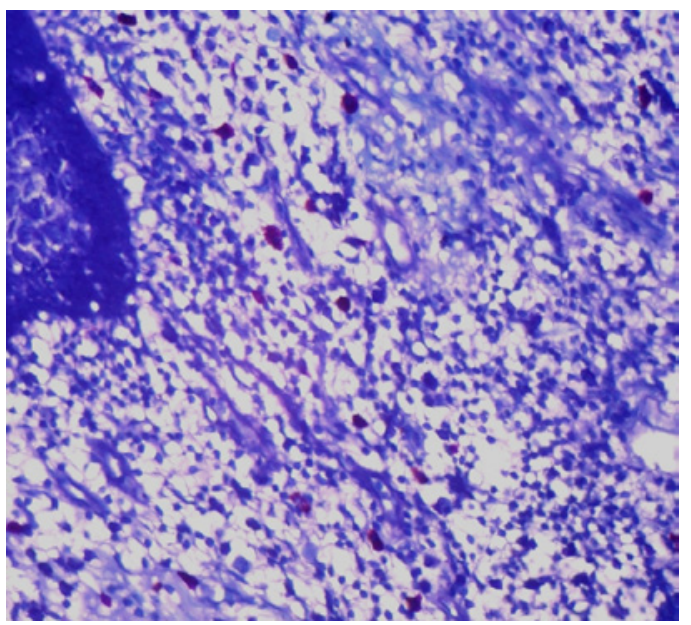

Figure 2: Toluidine blue stained OSCC section showing mast cells.

\begin{tabular}{|c|c|c|}
\hline Site & No. of cases & Percentage (\%) \\
\hline Buccal Mucosa & 10 & 33.33 \\
\hline Mandibular Alveolus & 8 & 26.66 \\
\hline Tongue & 4 & 13.33 \\
\hline Alveolus and Buccal Mucosa & 2 & 6.66 \\
\hline Alveolus and Labial Vestibule & 3 & 10.00 \\
\hline Floor of mouth & 1 & 3.33 \\
\hline Maxilla & 2 & 6.66 \\
\hline Total & 30 & 100.00 \\
\hline
\end{tabular}

Table 1: Site wise distribution of lesion.

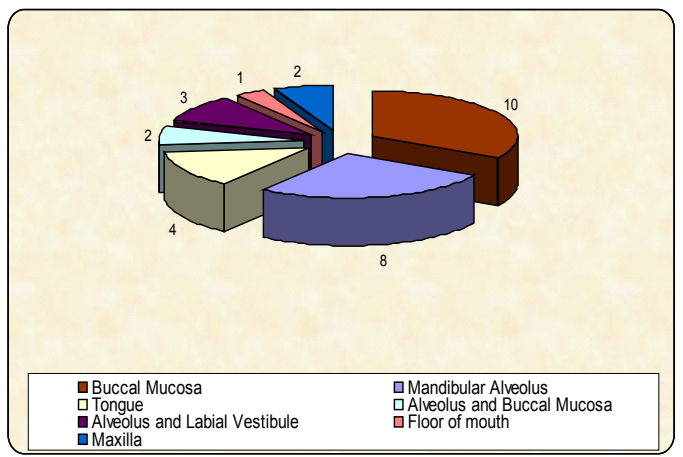

Figure 3: Site wise distribution of lesion.

with chemotherapy or radiotherapy before surgery. 2) Tumours with extensive ulceration and/or necrosis.

\section{Results}

The data was collected from all cases and organized in a systemic manner. All data was formulated in graphs derived from statistical analysis for interpretation of results. Table 1 and Figure 3 depict site wise distribution of lesion and shows that maximum number of cases $33.33 \%$ had lesion on the buccal mucosa. Table 2 and Figure 4 shows statistically significant positive correlation $(\mathrm{P}<0.05)$ between infiltration of tissue eosinophil and mast cell in OSCC. Table 3 and Figure 5 shows statistically significant $(\mathrm{P}<0.05)$ influence of tissue eosinophil on prognosis of OSCC and suggest that increased eosinophils infiltration related with good prognosis. Table 4 and Figure 6 shows statistically significant influence of mast cell on prognosis of OSCC which suggest significant favourable prognostic influence of mast cells infiltration in OSCC. So the results of present study show that both cells i.e. tissue eosinophils and mast cell infiltration is suggestive of favourable prognosis in OSCC.

\section{Discussion}

Oral cancer is an important cause of morbidity and mortality. The World Health Organization expects a worldwide rise in the OSCC incidence in the next decades [1,2]. This motivates the search for factors with prognostic relevance in order to better tailor the individual management of OSCC patients.

Tumour stroma consists of various inflammatory cells. Regarding role of TATE and mast cells in tumour stroma various studies which have been conducted but still it is not clear that whether tissue eosinophil/mast cell contribute to the body defense against tumours or are associated with tumour progression [10]. Thus considering the controversy surrounding the role of tissue eosinophils and mast cells 
in OSCC, our study designed to evaluate the prognostic significance of tissue eosinophil and mast cell infiltration in OSCC. A retrospective study, with the sample size of 30 histopathologically diagnosed cases of oral squamous cell carcinoma, was carried out. The cases were followed up for a minimum period of 3 years.

Out of thirty cases, maximum number of cases $33.33 \%$ had lesion on the buccal mucosa (Table 1 and Figure 3). This may be due to predominant habit of tobacco chewing. We found that both cells i.e. tissue eosinophil and mast cell infiltration significantly correlated with each other (Table 2 and Figure 4). The increase in number of eosinophil was also reflected by increase infiltration of mast cell, as mast cell secrets ECF (Eosinophil chemoattractant factor) which attract tissue eosinophils [12,13]. Regarding the prognostic important of tumour associated tissue eosinophils in OSCC, we found that in patients who had survived for 3 years or more, tissue eosinophil count is increased in comparison to patients who had survived for less than 3 years. Our data shows the significant favourable prognostic influence of tissue eosinophil in OSCC (Table 3 and Figure 5). Our results are in concordance with studies done in by Lowe and Fletcher [14], Gold

\begin{tabular}{|c|c|c|}
\hline Tissue eosinophil and Mast Cell & Statistics & Significance \\
\cline { 1 - 2 } Correlation & 0.42 & Significant \\
p-value & 0.01 & $\mathrm{P}<0.05$ \\
\hline
\end{tabular}

Table 2: Correlation of Tissue eosinophil and Mast Cell in OSCC patients Spearman's Rank Correlation Coefficient.

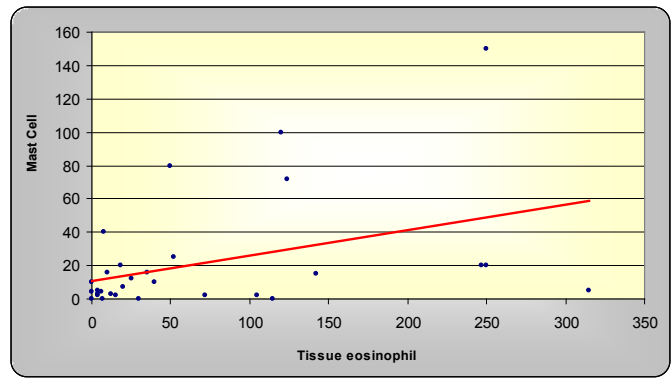

Figure 4: Correlation of Tissue eosinophil and Mast Cell in OSCC patients.

\begin{tabular}{|c|c|c|c|}
\hline Prognosis of OSCC & $\begin{array}{c}\text { Alive } \\
(\geq 3 \mathrm{yrs})\end{array}$ & $\begin{array}{c}\text { Dead } \\
(<3 \mathrm{yrs})\end{array}$ & $\begin{array}{c}\text { Krushkal Wallis Test } \\
\left(\boldsymbol{k}^{2} \text {-value }\right)\end{array}$ \\
\hline $\begin{array}{c}\text { Tissue eosinophil } \\
\text { Mean } \pm \text { SD }\end{array}$ & $124.35 \pm 102.70$ & $21.18 \pm 31.33$ & $\begin{array}{c}13.10 \\
p \text {-value }=0.000 \\
\text { S, } p<0.05\end{array}$ \\
\hline
\end{tabular}

Table 3: Influence of Tissue eosinophil on prognosis of OSCC.

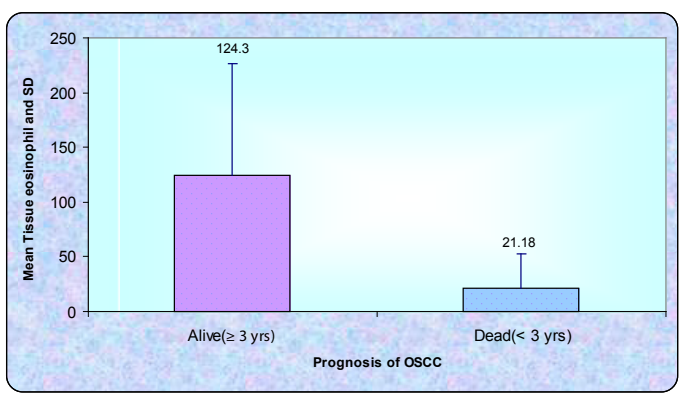

Figure 5: Influence of Tissue eosinophil on prognosis of OSCC.

\begin{tabular}{|c|c|c|c|}
\hline Prognosis of OSCC & $\begin{array}{c}\text { Alive } \\
(\geq 3 \mathrm{yrs})\end{array}$ & $\begin{array}{c}\text { Dead } \\
(<3 \mathrm{yrs})\end{array}$ & $\begin{array}{c}\text { Krushkal Wallis Test } \\
\left(\boldsymbol{k}^{2} \text {-value }\right)\end{array}$ \\
\hline Mast cell Mean \pm SD & $41.21 \pm 43.30$ & $4.25 \pm 4.49$ & $\begin{array}{c}15.33 \\
p \text {-value }=0.000 \\
\mathrm{~S}, \mathrm{p}<0.05\end{array}$ \\
\hline
\end{tabular}

Table 4: Influence of Mast Cell on prognosis of OSCC.

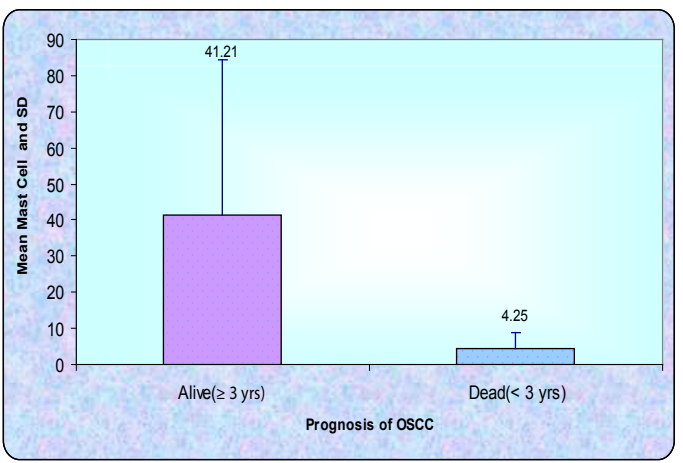

Figure 6: Influence of Mast Cell on prognosis of OSCC.

Smith et al. [5], Gold Smith et al. [15], Gao [16] and Dorta et al. [17]. All these studies favours that increased number of tissue eosinophil association with good prognosis.

Tumour associated eosinophil has also been studied in various other malignancies of the body like malignancies of larynx, oesophagus, nasopharynx [18-20]. All these studies suggest that tumour associated tissue eosinophils are associated with favourable prognosis and this is indicative of good immune response of the body. But it remain unknown whether it is the eosinophils themselves that lead to the improved prognosis or simply that tissue eosinophilia is a coincidental epiphenomenon initiated by a more fundamental biologic process. There is some experimental evidence for the former, since it has been shown that the growth of implanted tumours is inhibited if the proposed implanted site has eosinophilia [19]. Direct damage to mammalian tumour cells by the eosinophil mediated peroxidase system has also been demonstrated. TNF-alpha, secreted by eosinophils, also plays an important role in OSCC, as it causes death of tumour cells [17]. All these studies suggest that increase infiltration of tissue eosinophils associated with the favourable prognosis and indicative of an antitumoural role of tumour associated tissue eosinophils.

In our study we have also evaluated the prognostic influence of mast cells infiltration in OSCC. We found that in patients who had survived for 3 years or more, mast cell count is increased in comparison to patients who had survived for less than 3 years. Our data shows a significant favourable prognostic influence of mast cell in OSCC (Table 4). This result are in concordance with various studies done by Alkhabuli et al. [10], Tanooka et al. [21], Sand et al. [22], Samoszuk et al. [23], Ch'ng et al. [24], Sinnamon et al. [25] and Ueda et al. [26]. All these studies have provided evidence for the association of increase number of mast cells with favorable prognosis and suggest that mast cells play a antitumoural role.

Antitumoural role of mast cells is explained by various mediators that are detrimental to the tumour including cytokines IL-1, IL-4, IL-6 which induces apoptosis of tumour cells and chondroitin sulphate inhibits metastasis. Mast cells also produce TNF-alpha, is directly cytotoxic to tumour cells [24,27]. In experimental mice it has been seen 
Citation: Debta P, Debta FM, Chaudhary M, Wadhwan V (2011) Evaluation of Prognostic Significance of Immunological Cells (Tissue Eosinophil and Mast Cell) Infiltration in Oral Squamous Cell Carcinoma. J Cancer Sci Ther 3: 201-204. doi:10.4172/1948-5956.1000089

that mast cell deficient mice had an increased tumour incidence after treatment with a carcinogenic agent [21]. Thus all this evidence suggest that tumour associated tissue mast cell play a role in antitumoural activity and thus show association with a favourable prognosis.

All evidence suggests that both tissue eosinophils and mast cells provide defense against tumour progression. In our study all findings suggest that increase infiltration of tissue eosinophils and mast cells associated with favourable prognosis in OSCC.

\section{Conclusion}

Cancer kills or maims thousands of lives each day. Despite enormous efforts to find a cure, overall survival of cancer patients has not increased and the main barrier is a limited understanding of the biology of tumour. So in the search of new prognostic and predictive factors for OSCC we conclude that increase infiltration of tissue eosinophils and mast cells associated with favourable prognosis in OSCC. Thus quantitative assessment of eosinophils and mast cells are the most important aspects of the microscopic evaluation of OSCC.

\section{References}

1. Gupta PC, Nandakumar A (1999) Oral cancer scene in India. Oral Dis 5: 1-2.

2. Massano J, Regateiro FS, Januario G, Ferreira A (2006) Oral squamous cell carcinoma: Review of prognostic and predictive factors. Oral Surg Oral Med Oral Pathol Oral Radiol Endod 102: 67-76.

3. Bankfalvi A, Piffko J (2000) Prognostic and predictive factors in oral cancer: the role of invasive tumour front. J Oral Pathol Med 29: 291-298.

4. Lopes MA, Nikitakis NG, Reynolds MA, Ord RA, Sauk J Jr (2002) Biomarkers predictive of lymph node metastases in oral squamous cell carcinoma. J Oral Maxillofac Surg 60: 142-147.

5. Goldsmith MM, Cresson DH, Askin FB (1987) The prognostic significance of stromal eosinophilia in head and neck cancer. Otolaryngol Head Neck Surg 96: 319-324.

6. Dorta RG, Landman G, Kowalski LP, Lauris JR, Latorre MR. (2002) Tumorassociated tissue eosinophilia as a prognostic factor in OSCCs. Histopathology 41: 152-157.

7. Horiuchi K, Mishima K, Ohsawa M, Sugimura M, Aozasa K (1993) Prognostic factors for well differentiated squamous cell carcinoma in the oral cavity with emphasis on immunohistochemical evaluation. J Surg Oncol 53: 92-96.

8. Woolgar JA (2006) Histopathological prognosticators in oral and oropharyngeal squamous cell carcinoma. Oral Oncol 42: 229-239.

9. Anneroth G, Hansen LS, Silverman S Jr (1986) Malignancy grading in oral squamous cell carcinoma. I. Squamous cell carcinoma of the tongue and floor of mouth: histologic grading in the clinical evaluation. J Oral Pathol 15: 162 168

10. Alkhabuli JO (2007) Significance of neo-angiogenesis and immuno-surveillance cells in squamous cell carcinoma of the tongue. Libyan J Med 2: 30-39.

11. Culling CFA, Allison RT, Barr WT (1985) Miscellaneous cells. In, Culling CFA. Cellular pathology technique. $4^{\text {th }}$ edition. London Butterworth and Co. Ltd, 460461.

12. Lewis SM, Bain BJ, Bates I (2006) Dacie and Lewi's practical haematology, $10^{\text {th }}$ edition, Philadelphia, Churchill Livingstone, 14-15.

13. Weller PF, Goetzl EJ (1980) The Human Eosinophil: Role in host defense and tissue injury. Am J Pathol 100: 793-820.

14. Lowe D, Fletcher CD (1984) Eosinophilia in squamous cell carcinoma of the oral cavity, external genitals and anus- Clinical correlations. Histopathology 8 : 627-632

15. Goldsmith MM, Belchis DA, Cresson DH, Merrit WD, Askin FB (1992) The importance of eosinophils in head and neck cancer. Otolaryngol Head Neck Surg 106: 27-33.
16. Gao J, HeY, WuL (1997) The clinical analysis of eosinophil infiltration in human squamous cell carcinoma of buccal mucosa. Hua Xi Kou Qiang Yi Xue Za Zhi 15: $228-232$.

17. Dorta RG, Landman G, Kowalski LP, Lauris JR, Latorre MR. (2002) Tumorassociated tissue eosinophilia as a prognostic factor in OSCCs. Histopathology 41: 152-157.

18. Thompson AC, Bradley PJ, Griffin NR (1994) Tumor-Associated tissue eosinophilia and long-term prognosis for carcinoma of the larynx. Am J Surg 168: 469-471.

19. Ohashi Y, Ishibashi S, Suzuki T, Shineha R, Moriya T, et al. (2000) Significance of tumor associated tissue eosinophilia and other inflammatory cell infiltrate in early esophageal squamous cell carcinoma. Anticancer Res 20: 3025-3030.

20. Fujii M, Yamashita T, Ishiguro R, Tashiro M, Kameyama K (2002) Significance of epidermal growth factor receptor and tumor associated tissue eosinophilia in the prognosis of patients with nasopharyngeal carcinoma. Auris Nasus Larynx 29: $175-181$.

21. Tanooka H, Kitamura Y, Sado T, Tanaka K, Nagase M, et al. (1982) Evidence for involvement of mast cells in tumor suppression in mice. J Natl Cancer Inst 69: 1305-1309.

22. Sand L, Hilliges M, Larsson PA, Wallstrom M, Hirsch JM (2002) Effects of longterm administration of cancer-promoting substances on oral subepithelial mast cells in the rat. Anticancer Res 22: 2623-2627.

23. Samoszuk M, Kanakubo E, Chan JK (2005) Degranulating mast cells in fibrotic regions of human tumors and evidence that mast cell heparin interferes with the growth of tumor cells through a mechanism involving fibroblasts. BMC cancer 5: 121.

24. Ch'ng S, Sullivan M, Yuan L, Davis P, Tan ST (2006) Mast cells dysregulate apoptotic and cell cycle genes in mucosal squamous cell carcinoma. Cancer Cell Int 6: 28.

25. Sinnamon MJ, Carter KJ, Sims LP, LaFleur B, Fingleton B, et al. (2008) A protective role of mast cells in intestinal tumorigenesis. Carcinogenesis 29 : 880-886.

26. Ueda T, Aozasak, Tsujimoto M, Yoshikawa H, Kato T, et al. (2008) Prognostic significance of mast cells in soft tissue sarcoma. Cancer 62: 2416-2419.

27. Theoharides TC, Conti P (2004) Mast cells: the Jekyll and Hyde of tumor growth. Trends Immunol 25: 235-241. 